\title{
GLOSY
}

\author{
ANETA PALECZNA \\ https://doi.org/10.33995/wu2020.1.4
}

\section{Glosa do wyroku Sądu Najwyższego z dnia 24 stycznia 2017 roku sygn. V CSK $163 / 16^{1}$}

Niniejsza publikacja stanowi próbę analizy ochrony ubezpieczeniowej w gospodarstwach rolnych oraz jej skuteczności. Opracowanie zawiera rozważania na temat pojęcia gospodarstwa rolnego. W polskim systemie prawnym istnieja różnorodne definicje gospodarstwa rolnego. Służq one do realizacji odmiennych celów. Gospodarstwo rolne jest masq majatkowa połaczonq funkcjonalnie, a w konsekwencji wszystkie jego składniki sq połączone więziq funkcjonalnq. Na tym tle w sposób szczególny zarysowuje się zagadnienie składników gospodarstwa rolnego. W orzecznictwie podjęto bowiem próbę określenia, czy i w jakich sytuacjach basen oraz zwierzęta, takie jak psy albo konie, sq objęte ochrona ubezpieczeniowa.

W ramach niniejszego artykułu autorka uwzględniła również założenia włoskiego systemu prawnego. Omówiła także zmiany legislacyjne, które maja na celu dostosowanie produktu ubezpieczeniowego do potrzeb klienta.

Słowa kluczowe: gospodarstwo rolne, masa majątkowa, więź funkcjonalna, ubezpieczenia, zwierzęta gospodarskie.

Do wydania wyroku Sądu Najwyższego prowadził stan faktyczny, w którym pozwany był właścicielem gospodarstwa ogrodniczego i prowadził działalność rolniczą, zaś jego małżonka - pozwana - prowadziła działalność gospodarczą, a nadto wspierała męża w prowadzeniu gospodarstwa. Począwszy od 1997 roku w gospodarstwie tym zatrudniona była matka powoda.

W dniu 19 marca 2009 roku pozwana skontaktowała się z matką powoda i zwróciła się do niej prośba o stawienie się następnego dnia w pracy, ze względu na transport roślin i konieczność ich rozplantowania. Ta oznajmiła, że nie ma komu powierzyć opieki nad dzieckiem, w odpowiedzi na co pozwana zaproponowała, aby zabrała je ze soba. Wcześniej zdarzało się bowiem, że pracownica zabierała dziecko ze soba do pracy, co pozwani akceptowali. W dniu zdarzenia, tj. 20 marca

1. Legalis nr 1618261. 
2009 roku, matka małoletniego przyszła do pracy wraz z synem. Matka powoda sadziła kwiaty wraz z pozwana, zaś małoletniemu zezwoliła pójść do pozwanego, który przebywał w pomieszczeniu pracowni na końcu gospodarstwa ogrodniczego, oraz do psów, znajdujących się w pobliżu jej miejsca pracy. Pozwana się temu nie sprzeciwiła. Gdy małoletni przez jakiś czas nie wracał, matka zaczęła go szukać. Znalazła syna w basenie pływającego na powierzchni wody, z twarza skierowaną do dołu. Gdy wyciagnęła go z wody, rozpoczęła reanimację, która trwała do przyjazdu pogotowia. Po przyjeździe karetki lekarka podjęła próbę przywrócenia oddechu, po czym zaprzestała reanimacji, uznając, że nie małoletni nie daje oznak życia. Pozostałe osoby kontynuowały reanimację do czasy przyjazdu kolejnej karetki. Po jej przyjeździe reanimację podjęła obsługa karetki. Małoletni został przewieziony do szpitala, gdzie ostatecznie uzyskano powrót akcji serca. W placówkach medycznych powód przebywał do dnia 21 stycznia 2010 roku, zaś do dnia 3 marca 2010 roku w hospicjum. Rozpoznano u niego szereg dolegliwości, takich jak: stan po utonięciu, niewydolność wielonarządową, zespół rozsianego krzepnięcia śródnaczyniowego, zespół uogólnionej reakcji zapalnej. Pomimo leczenia powód jest osobą leżąca, bez kontaktu słownego, z wieloma dolegliwościami. Jego oddech jest wspomagany przez aparaturę, kończyny pozostają w zgięciu z przykurczami. Małoletni doznał łącznego uszczerbku na zdrowiu wynoszącego $310 \%$. Od dnia 3 marca 2010 roku powód przebywa u rodziców, pod stałą opieką matki.

Równolegle Prokuratura Rejonowa wszczęła dochodzenie w sprawie narażenia powoda w dniu 21 marca 2009 roku przez jego matkę na bezpośrednie niebezpieczeństwo utraty życia lub ciężkiego uszczerbku na zdrowiu. Postanowieniem z dnia 30 czerwca 2009 roku zostało ono umorzone wskutek braku wniosku osoby uprawnionej. Prokuratura Rejonowa skierowała również akt oskarżenia przeciwko lekarce pogotowia ratunkowego i zarzuciła jej popełnienie przestępstwa z art. 160 § 2 k.k.

Sąd Okręgowy stwierdził, że pozwany, prowadząc działalność ogrodniczą i zatrudniając pracowników, powinien zapewnić im bezpieczeństwo pracy (art. 207 § 1 k.p.), a w razie prowadzenia prac w miejscu, do którego miały dostęp osoby niezatrudnione, zastosować środki niezbędne do zapewnienia tym osobom ochrony życia i zdrowia (art. 304 § 4 k.p.). Co za tym idzie, dopuszczając do miejsca pracy małoletniego powoda, powinien zapewnić mu bezpieczeństwo. Obowiązek ten spoczywał także na pozwanej (art. 207 § 3 k.p.). Tymczasem pozwana akceptowała poruszanie się przez powoda po terenie gospodarstwa ogrodniczego bez jakiejkolwiek opieki, zaś basen nie był w żaden sposób zabezpieczony, mimo że ze względu na położenie i zlicowanie brzegów z terenem stanowił zagrożenie dla dziecka. W tym stanie rzeczy Sąd I instancji uznał, że pozwani ponosza odpowiedzialność za szkodę, jakiej doznał powód, a na podstawie art. 415 k.c. Sąd Okręgowy uznał ponadto, że pozwany ubezpieczyciel ponosi odpowiedzialność w granicach odpowiedzialności cywilnej pozwanych do ustalonej w umowie sumy gwarancyjnej, tj. 1500000 euro, albowiem spełnione zostały przesłanki z art. 50 ust. 1 u.o.ob. ${ }^{2}$. W konsekwencji, mając na względzie rozmiar szkody doznanej przez powoda, zasądził od pozwanych na rzecz powoda kwotę 500000 złotych, kwotę 27500 złotych oraz rentę w kwocie 2500 złotych miesięcznie ${ }^{3}$.

2. Ustawa z dnia 22 maja 2003 r. o ubezpieczeniach obowiązkowych, Ubezpieczeniowym Funduszu Gwarancyjnym i Polskim Biurze Ubezpieczycieli Komunikacyjnych (Dz. U. 2003, nr 124, poz. 1152).

3. Według danych International Social Security Association (ISSA) dwie trzecie dzieci, które giną w rolnictwie, ma poniżej lat pięciu, a najczęstszą przyczyną ich śmierci są wypadki z udziałem maszyn rolniczych oraz kierowców. Zob. E. Borowczyk, Zabezpieczenie społeczne, rodzina i jednostka, [w:] Europejskie Spotkanie Regionalne ISSA, Ubezpieczenia w rolnictwie, „Materiały i Studia” 1999, nr 3, s. 114. 
Apelacje od wyroku Sądu Okręgowego zostały wniesione przez pozwanego ubezpieczyciela oraz powoda. Sąd Apelacyjny, uznając zarzuty podniesione w obydwu apelacjach za bezzasadne, wskazał, że szkoda powstała w związku z posiadaniem gospodarstwa rolnego przez pozwanych, za czym przemawia jego położenie, przeznaczenie wody gromadzonej w basenie oraz jego wielkość. Obydwie apelacje zostały oddalone przez Sąd.

W skardze kasacyjnej od wyroku Sądu II instancji ubezpieczyciel zarzucił naruszenie prawa procesowego oraz prawa materialnego m.in. poprzez przyjęcie, że basen był związany z prowadzona przez pozwanych działalnością ogrodniczą, a co za tym idzie, że szkoda została wyrządzona w związku z posiadaniem przez rolnika gospodarstwa rolnego. Miałoby zatem dojść do dokonania błędnej wykładni pojęcia szkody związanej z posiadaniem przez rolnika gospodarstwa rolnego. Ubezpieczyciel konsekwentnie podniósł, że matka powoda przyczyniła się do powstania szkody, w sytuacji niemożności zapewnienia mu należytej opieki powinna bowiem odmówić wykonywania pracy.

Istota sprawy przedstawionej do rozpoznania Sądowi Najwyższemu sprowadzała się do poszukiwania odpowiedzi na pytanie, czy basen, w którym doszło do wypadku, był związany z prowadzona przez pozwanych działalności rolniczą, a w ślad za tym: czy szkoda została wyrządzona w związku z posiadaniem przez rolnika gospodarstwa rolnego. Drugim zagadnieniem wymagającym pogłębionej analizy był wpływ zachowania matki powoda (osoby trzeciej) na wysokość żądania powoda wobec pozwanego.

Z przepisu art. 50 u.u.ob. wynika, że odszkodowanie z ubezpieczenia OC rolników przysługuje za szkodę wyrządzoną „w związku z posiadaniem” przez rolnika gospodarstwa rolnego. Ów związek i powiązanie kauzalne zostało dostrzeżone przez Sąd Najwyższy w kontekście wcześniej obowiązujących regulacji, w których przesłanką uzyskania odszkodowania było nie tyle posiadanie gospodarstwa, co właśnie „związek z prowadzeniem gospodarstwa”4 albo „z tytułu prowadzenia gospodarstwa rolnego"

W pisemnych motywach orzeczenia słusznie wskazano, że definicja sformułowana w art. 2 ust. 1 pkt. 4 u.u.ob. ${ }^{6}$ nie jest definicja pełna, dlatego ocena, czy szkoda została wyrządzona w związku z posiadaniem gospodarstwa rolnego wymaga odwołania się do definicji zawartej w Kodeksie cywilnym.

W tym miejscu uzupełnienia jednak wymaga, że wprowadzenie definicji legalnej gospodarstwa rolnego do Kodeksu cywilnego ustawą nowelizująca z 28 lipca 1990 roku? nie usunęło zgłaszanych w doktrynie wątpliwości co do kryteriów wyodrębnienia gospodarstwa rolnego, zwłaszcza wobec

4. Rozporządzenie Ministra Finansów z dnia 30 grudnia 1993 r. w sprawie ogólnych warunków obowiązkowego ubezpieczenia odpowiedzialności cywilnej rolników z tytułu prowadzenia gospodarstwa rolnego (Dz. U. 1993, nr 134, poz. 653 z późn. zm.).

5. Rozporządzenie Ministra Finansów z dnia 18 grudnia 1990 r. w sprawie ogólnych warunków ubezpieczenia odpowiedzialności cywilnej rolników z tytułu prowadzenia gospodarstwa rolnego (Dz. U. nr 89, poz. 526 z późn. zm.].

6. Definicja zaproponowana w art. 2 ust. 1 pkt. 4 ustawy z 22 maja 2003 r. o ubezpieczeniach obowiązkowych, Ubezpieczeniowym Funduszu Gwarancyjnym i Polskim Biurze Ubezpieczycieli Komunikacyjnych, dzieląca gospodarstwa na dwa rodzaje: przekraczające powierzchnię 1 ha oraz, niezależnie od powierzchni, o ile prowadzona jest na nich produkcja rolna, stanowiąca dział specjalny w rozumieniu przepisów o podatku dochodowym od osób fizycznych

7. Ustawa z 28 lipca 1990 r. o zmianie ustawy - Kodeks cywilny, tekst jedn. Dz. U. 1990, nr 55, poz. 321. 
faktu, że normatywna definicja ma służyć celom społeczno-gospodarczym ${ }^{8}$. Definicja ta jest wyrazem gruntowej koncepcji gospodarstwa rolnego ${ }^{9}$. Analiza pojęcia gospodarstwa rolnego skłania zresztą do refleksji o jego niejednolitości, co potwierdza stanowisko wyrażone przez Trybunał Sprawiedliwości Unii Europejskiej ${ }^{10}$. Pierwotnie twierdzono, że w oparciu o traktat rzymski nie można sformułować ogólnej definicji gospodarstwa rolnego ${ }^{11}$. Następnie uznano, że gospodarstwo rolne to pewien potencjalny zespół elementów produkcyjnych, które mogą być wykorzystane do produkcji rolnej ${ }^{12}$. W szczególności powierzchnie użytków rolnych są przyporządkowane do gospodarstwa rolnika, gdy owemu rolnikowi przysługuje uprawnienie do zarządzania nimi do celów prowadzenia działalności rolniczej, to znaczy, gdy rolnik ten dysponuje w odniesieniu do tych powierzchni wystarczającą samodzielnością przy prowadzeniu działalności rolniczej ${ }^{13}$.

Z powyżej omówionych przyczyn w prawie włoskim kształt normatywny gospodarstwa rolnego został wyznaczony przez dorobek judykatury i piśmiennictwa. W ujęciu włoskim w miejsce definicji legalnej gospodarstwa rolnego ukształtowały się dwie koncepcje: cywilistyczna i prawno-handlowa. Według pierwszej z nich gospodarstwo rolne to grunt rolny wraz z przynależnościami (fundus instructus; aspekt własnościowy). Istota drugiej sprowadza się do uznania związku gospodarstwa rolnego z rolniczą działalnościa gospodarcza ${ }^{14}$.

Powracając w tym miejscu do definicji gospodarstwa rolnego przyjętych na gruncie rodzimego prawodawstwa, należy zaznaczyć, iż rodzą one wiele problemów praktycznych.

W pierwszej kolejności: w doktrynie i judykaturze nie wypracowano jednolitego stanowiska co do charakteru przytoczonej definicji. Choć dominuje pogląd o funkcjonalnym ujęciu gospodarstwa rolnego ${ }^{15}$, to w orzecznictwie pojawiają się poglądy o jego aspekcie materialnym ${ }^{16}$. Na tym

8. Wyrok SN z 28 listopada 2001 r., sygn. akt: IV CKN 500/00, Legalis nr 278020; wyrok SR w Wieluniu - VIII Zamiejscowy Wydział Cywilny z siedzibą w Pajęcznie z 19 grudnia 2016 r., sygn. akt: VIII C 100/16, Legalis nr 2090746; wyrok SA we Wrocławiu z 14 czerwca 2013 r., sygn. akt: I ACa 521/13, Legalis nr 743616.

9. Zgodnie $z$ art. $55^{3}$ k.c. za gospodarstwo rolne uważa się grunty rolne wraz z gruntami leśnymi, budynkami lub ich częściami, urządzeniami i inwentarzem, jeżeli stanowią lub mogą stanowić zorganizowaną całość gospodarczą, oraz prawami związanymi z prowadzeniem gospodarstwa rolnego. Zob. E. Skowrońska-Bocian, M. Warciński, [w:] Kodeks cywilny. Tom I. Komentarz. Art. 1-44910, [red.] K. Pietrzykowski, CH Beck, Warszawa 2015, s. 249; R. Budzinowski, Pojęcie gospodarstwa rolnego według kodeksu cywilnego (rozważania na tle art. 55 k.c.), „Ruch Prawniczy, Ekonomiczny i Socjologiczny” 1991, nr 3, s. 66.

10. Także w odniesieniu do gruntów rolnych Trybunał Sprawiedliwości dostrzegł współistnienie różnych pojęć definiujących kwalifikowalne grunty rolne. Zob. wyrok z 5 grudnia 2018 r., sygn. akt: C-341/1?, Republika Grecka przeciwko Komisji Europejskiej, http://curia.europa.eu/juris/document/document.jsf?text=gospod arstwo\%2Brolne\&docid=208503\&pagelndex=0\&doclang=pl\&mode=req\&dir=\&occ=first\&part $=1 \& \mathrm{ccid}=39$ 28726\#ctx1 [dostęp: 23.11.2019].

11. Wyrok z 28 lutego 1978 r., sygn. akt: 85/77 Azienda Avicola Sant'Anna, Zb.0. S. 1978, s. 527.

12. Wyrok z 13 lipca 1989 r., sygn. akt: 5/88, Wachau fv. RFN, Zb.0. T. S. z 1989, s. 2609.

13. Por. wyrok z 14 października 2010 r., sygn. akt: C-61/09, Landkreis Bad Dürkheim, EU:C:2010:606, pkt 58, 62; wyrok z 2 lipca 2015 r., sygn. akt: C-422/13, Wree, EU:C:2015:438, pkt 44.

14. A. Szymecka, Gospodarstwo rolne w prawie włoskim - zagadnienia wybrane, „Przegląd Prawa Rolnego” 2009, nr 1, s. 165.

15. E. Skowrońska-Bocian, M. Warciński, op. cit., s. 249.

16. „Przepis art. $55^{3}$ k.c. akcentuje przede wszystkim aspekt materialny, funkcja gospodarstwa rolnego w tym przypadku ma poboczne znaczenie". Zob. wyrok SA w Białymstoku z 18 lutego 2014 r., sygn. akt: III AUa 1003/13, LEX nr 1427986. 
tle, odnosząc się do minimalnej powierzchni nieruchomości wchodzących w skład gospodarstwa rolnego, Sąd Najwyższy w wyroku z 2 czerwca 2000 roku uznał, że ta jednostka gospodarcza zorganizowana na nieruchomości powinna mieć taki obszar, na którym możliwe jest prowadzenie działalności wytwórczej przeznaczonej na zbyt ${ }^{17}$. Sąd Najwyższy zdystansował się zarazem od rozważań zawartych w wyroku z 5 lutego 1998 roku ${ }^{18}$. Z pewnością inaczej rzecz się ma gruncie pozostałych ustaw ${ }^{19}$. Interesujące rozwiązanie zostało przewidziane w ustawie włoskiej, która nie wymaga obecności gruntów rolnych wśród składników gospodarstwa, co oznacza, iż można prowadzić działalność rolniczą bez władania nieruchomością ${ }^{20}$. Rozwiązanie to pozostaje o tyle cenne, że doprowadziło do wypracowania wielu modeli gospodarstwa rolnego we włoskim porządku prawnym.

Kolejną watpliwość, kluczową na gruncie glosowanego orzeczenia, wzbudza stopień zorganizowania gruntów wchodzacych w skład gospodarstwa rolnego. Część autorów wskazuje, iż poszczególne składniki gospodarstwa rolnego stanowią albo powinny stanowić zorganizowana całość gospodarczą ${ }^{21}$. Z kolei w orzecznictwie pojawiają się poglady, iż gospodarstwo rolne tworza grunty położone na dowolnym obszarze, również wtedy, gdy nie istnieje pomiędzy nimi żadna więź gospodarcza, a nawet gdy z uwagi na ich położenie nie mogą one stanowić zorganizowanej całości ${ }^{22}$. Brak jednomyślności szczególnie wyraźnie rysuje się na tle wyliczenia z art. $55^{3}$ k.c. Jedni autorzy opowiadają się za zamkniętym katalogiem składników gospodarstwa rolnego, a pozostali wskazują, iż jest to wyliczenie o charakterze przykładowym ${ }^{23}$. Judykatura również nie dostarcza w tym zakresie zadowalających i stanowczych poglądów. Wskazuje się, iż termin inwentarz obejmuje zwierzęta, maszyny, narzędzia, zaś przez inne urządzenia rozumieć należy np. studnie, szklarnie, magazyny, urządzenia do hodowli ryb itp. ${ }^{24}$

Staranna analiza dorobku judykatury prowadzi do wniosku, iż gospodarstwo rolne stanowi zorganizowany konglomerat składników, zaś wybór definicji - podobnie jak w niniejszej sprawie - podyktowany będzie okolicznościami konkretnej sprawy. Analiza przedstawionych wyżej wypowiedzi piśmiennictwa i judykatury pozwala na sformułowanie wniosku, że w nauce polskiej mnogość definicji gospodarstwa rolnego przekłada się na trudności z oceną poszczególnych jego składników.

Ustawodawca, wymieniając składniki gospodarstwa rolnego, uwydatnia ich znaczenie produkcyjne oraz włączenie do całości gospodarczej, nie posługując się kategoriami prawnorzeczowymi.

17. Wyrok SN z 2 czerwca 2000 r., sygn. akt: II CKN 1067/98, 0SP 2001, nr 2, poz. 2 .

18. Wówczas przyjęto, iż warunkiem istnienia gospodarstwa rolnego nie jest powierzchnia wchodzących jego skład nieruchomości. Jednocześnie ustawodawca pośrednio zakłada, iż gospodarstwem rolnym może być gospodarstwo mające obszar mniejszy niż 1 ha. Zob. wyrok SN z 5 lutego 1998 r., sygn. akt: I PKN 511/9?, OSNP 1999, poz. 1, nr 19.

19. Na gruncie ustawy o podatku rolnym podstawowym warunkiem uznania gruntów za gospodarstwo rolne jest ich łączna powierzchnia, nazywana normą obszarowa. Zob. wyrok WSA w Szczecinie z 29 kwietnia 2015 r., sygn. akt: I SA/Sz 186/15, LEX nr 1764913.

20. A. Szymecka, op. cit., s. 167-168.

21. E. Skowrońska-Bocian, M. Warciński, op. cit., s. 249. Zob. także wyrok WSA w Bydgoszczy z 12 sierpnia 2015 r., sygn. akt: II SA/Bd 195/15, LEX nr 1851993.

22. Wyrok WSA w Gorzowie Wielkopolskim z 4 października 2017 r., sygn. akt: I SA/Go 291/17, LEX nr 2375326.

23. Tak: E. Skowrońska-Bocian, M. Warciński, op. cit., s. 250; R. Budzinowski, Koncepcja gospodarstwa rolnego w prawie rolnym, Wydawnictwo Naukowe Uniwersytetu im. Adama Mickiewicza, Poznań 1992, s. 79.

24. Wyrok WSA w Gorzowie Wielkopolskim z 25 marca 2015 r., sygn. akt: II SA/Go 79/15, LEX nr 1937428. 
To oznacza, że rzeczy ruchome nie muszą być jednocześnie przynależnościami gruntu wchodzącego w skład gospodarstwa rolnego, a właściciel nieruchomości nie musi być jednocześnie właścicielem maszyn czy inwentarza ${ }^{25}$. W tym znaczeniu gospodarstwo rolne jest zespołem różnorodnych składników, tworzących zorganizowaną całość gospodarczą. Obejmuje ono prawa do rzeczy, zwierząt oraz prawa i obowiązki związane z prowadzeniem działalności o określonym profilu²6.

W świetle powyższych rozważań można uznać, że basen stanowi część składową nieruchomości wchodzạcej w skład gospodarstwa rolnego pozwanych. Ten materialny składnik, jakim jest grunt - niezależnie od tego, czyją stanowi własność - niewatpliwie był wykorzystywany do prowadzenia działalności ogrodniczej. Na nieruchomości znajdował się bowiem nie tylko basen ale także szklarnia, pracownia, tunel foliowy oraz rośliny. Tworzył z pozostałymi składnikami funkcjonalną całość. Z kolei basen wykorzystywany był do prowadzenia działalności ogrodniczej, umożliwiał podlewanie roślin i sadzonek, a zatem pozwalał na gospodarowanie i osiaganie określonych efektów. Korzystali z niego pracownicy pozwanych. Basen ten znajdował się - jak zauważył Sąd - na terenie nieruchomości wchodzącej w skład gospodarstwa rolnego i nie mógł zostać odłączony od gruntu bez jego uszkodzenia albo istotnej zmiany.

Równie istotnym kryterium dla ustalenia zakresu odpowiedzialności ubezpieczyciela z tytułu ubezpieczenia OC rolników jest zakres pojęcia „szkoda związana z posiadaniem gospodarstwa rolnego". W tym kontekście należy zwrócić uwagę, iż pojęcie posiadania jest rozumiane szerzej - zarówno jako posiadanie, jak i prowadzenie gospodarstwa rolnego ${ }^{27}$.

W piśmiennictwie trafnie zwraca się uwagę na konieczność przeprowadzenia dwustopniowego testu mającego na celu ustalenie zaistnienia adekwatnego związku przyczynowego pomiędzy posiadaniem gospodarstwa rolnego a zaistniałą szkodą. W pierwszej kolejności, ubezpieczyciel nie ponosi odpowiedzialności, jeżeli szkoda powstałaby, nawet gdyby rolnik nie był posiadaczem gospodarstwa rolnego. Jeżeli jednak ubezpieczyciel ponosi odpowiedzialność, to należy ustalić, czy w okolicznościach faktycznych danej sprawy posiadanie gospodarstwa rolnego zwiększało prawdopodobieństwo wystapienia szkody, co oznaczać będzie, iż związek przyczynowy ma charakter normalny ${ }^{28}$.

Trzeba jednak uzupełnić stanowisko wyrażone w głosowanym orzeczeniu o twierdzenie, że nie każdy sposób korzystania ze składników majątkowych wchodzących w skład gospodarstwa rolnego

25. R. Budzinowski, [w:] Kodeks cywilny. Tom I. Komentarz. Art. 1-44911, [red.] M. Gutowski, Warszawa 2016, Legalis/el.

26. Wyrok SN z 12 kwietnia 2013 r., sygn. akt: IV CSK 565/12, LEX nr 1324321.

27. J. Nawracała, [w: Prawo ubezpieczeń gospodarczych. Komentarz. Tom I. Komentarz do przepisów prawnych o funkcjonowaniu rynku ubezpieczeń, [red.] Z. Brodecki, M. Glicz, M. Serwach, Wolters Kluwer, Warszawa 2010, s. 880; G. Wolak, Odpowiedzialność za szkodę wyrzqdzona przez psa wykorzystywanego przez rolnika użytkowo w gospodarstwie rolnym w świetle przepisów ustawy o ubezpieczeniach obowiqzkowych, „Prawo Asekuracyjne" 2017, nr 3, s. 51.

28. G. Wolak, op. cit., s. 44. Jak wskazuje się w orzecznictwie, w toku analizy, czy szkoda ma związek z prowadzeniem gospodarstwa rolnego, należy zwrócić uwagę na ruch tego przedsiębiorstwa, stan techniczny budynków i innych urządzeń w nim wykorzystywanych, w tym także składników materialnych mających postać czynnika zewnętrznego - nagłego, którego zaistnienie spowodowało powstanie sytuacji wpadkowej i wytworzenie układu sytuacyjnego, w którym powód, mając styczność z czynnikiem w postaci nieprawidłowo pozostawionego i unieruchomionego pojazdu, doznał szkody pozostającej w jakimkolwiek związku z działaniem lub zaniechaniem podmiotu prowadzącego gospodarstwo rolne. Zob. wyrok SR w Kaliszu, z 30 listopada 2017 r., sygn. akt: I C 98/15, Legalis nr 2060999. 
można uznać za równoznaczny z jego posiadaniem, a tylko taki, który jest związany z jego funkcjonowaniem jako zorganizowanego kompleksu gospodarczego ${ }^{29}$. Co więcej, odpowiedzialność za szkody związane z posiadaniem gospodarstwa rolnego pozwala na konkluzję, że ubezpieczyciel nie będzie ponosić odpowiedzialności za inne sfery aktywności życiowej osoby ubezpieczonej. Rozdzielenie zaś tych sfer czasami rodzi trudności ${ }^{30}$.

Sạd Najwyższy słusznie podzielił zapatrywanie Sadu Apelacyjnego w Katowicach, zgodnie z którym szkoda na osobie, jakiej doznał małoletni, stanowi szkodę wyrządzoną w związku z posiadaniem przez pozwanych gospodarstwa rolnego. Skarżący ubezpieczyciel oparł swoją linię argumentacyjną na twierdzeniu, że basen nie byłzwiązany z prowadzoną przez pozwanych działalnością ogrodniczą, lecz służył im do celów rekreacyjnych. Tymczasem w art. 50 ust. 1 u.u.o. chodzi o związek z posiadaniem gospodarstwa rolnego, a nie tylko z prowadzeniem działalności ogrodniczej. Innymi słowy, nawet jeżeli basen służył pozwanym do celów rekreacyjnych, nie zaś jako zbiornik do podlewania, to poprzez wykorzystywanie w gospodarstwie rolnym był związany z posiadanym gospodarstwem ogrodniczym. Z tej perspektywy należy każdorazowo analizować konkretny przypadek, a na gruncie postępowania sądowego rozważyć przeprowadzenie dowodu z opinii biegłego sądowego.

Wyrok Sądu Najwyższego z 24 stycznia 2017 roku wpisuje się w linię orzeczniczą zgodnie z którą ochroną ubezpieczeniową, której dotyczy wspomniany art. 50 u.u.o., nie jest objęty każdy rodzaj uszczerbku w dobrach osoby trzeciej wyrządzony przez rolnika czy przez osobę pracująca w jego gospodarstwie rolnym, czy też wynikły z użycia ruchomości lub zwierząt należących do rolnika ${ }^{31}$. Przepis ten wymaga, aby szkoda była objęta ochroną ubezpieczeniowa jako wyrządzona w związku z posiadaniem przez rolnika gospodarstwa rolnego. W wyroku z 12 kwietnia 2013 roku, Sąd Najwyższy zaprezentował pogląd, iż powstanie szkody, aby zostało objęte ubezpieczeniem OC rolnika, musi pozostawać w funkcjonalnym związku z tym gospodarstwem i jego prowadzeniem. Wyjęcie rzeczy (np. maszyny, urządzenia) z gospodarstwa rolnego prowadzonego przez rolnika i jej użycie poza tym gospodarstwem, w celu niezwiązanym z produkcją rolna, nie czyni szkody wyrządzonej przy wykorzystaniu tej rzeczy szkoda pozostającą w związku z prowadzeniem przez rolnika gospodarstwa rolnego. Dla przyjęcia, że taki związek zachodzi, nie wystarczy samo stwierdzenie, że konkretna rzecz należy do rolnika i pochodzi z jego gospodarstwa rolnego, w którym jest wykorzystywana.

W tym miejscu zasygnalizowania wymaga problematyka odpowiedzialności za szkody wyrzadzone przez zwierzęta wchodzące w skład gospodarstwa rolnego ${ }^{32}$. W piśmiennictwie i judykaturze zagadnienie to nie zostało jednoznacznie rozstrzygnięte ${ }^{33}$.

29. W konsekwencji szkoda wyrządzona przez stanowiącego składnik gospodarstwa rolnego konia, wykorzystywanego poza tym gospodarstwem w celach rekreacyjnych, nie jest objęta odpowiedzialnością gwarancyjna na podstawie art. 50 ust. 1 u.u.ob. Zob. wyrok Sądu Apelacyjnego w Białymstoku z dnia 30 kwietnia 2012 r., I ACa 730/11, Legalis nr 548619.

30. J. Nawracała, Komentarz do art. 50 u.u.ob., LEX.

31. Wyrok SN z 12 kwietnia 2013 r., sygn. akt: IV CSK 565/12, LEX nr 1324321; wyrok SR w Kaliszu z 30 listopada 2017 r., sygn. akt: I C 98/15, Legalis nr 2060999.

32. J. Nawracała, [w:] Prawo ubezpieczeń ..., s. 880.

33. Zob. szerzej: E. Kiziewicz, Odpowiedzialność rolnika za szkodę wyrzqdzonq przez psa, „Monitor Ubezpieczeniowy" 2015, nr 63; wyrok S0 w Łomży z 24 września 2014 r., sygn. akt: I Ca 122/14, LEX nr 1845888; wyrok SA w Lublinie z 13 stycznia 2015 r., sygn. akt: I ACa 656/14, LEX nr 1649032; wyrok SO w Zamościu z 14 lutego 
Drugim z zagadnień, które trafnie zaakcentował Sąd Najwyższy, jest żądanie zmniejszenia na podstawie art. 362 k.c. obowiązku odszkodowawczego wobec małoletniego na tej podstawie, że szkoda pozostaje w związku przyczynowym z zachowaniem rodziców małoletniego, którzy nie zapewnili mu należytego nadzoru. W wyroku z 2 grudnia 1982 roku ${ }^{34}$ Sąd Najwyższy co prawda wyraził pogląd, zgodnie z którym to właśnie charakter więzi pomiędzy dziećmi a rodzicami oraz obowiązki tych ostatnich pozwalają na przyjęcie, że przyczynienie się rodziców do powstania szkody jest równoznaczne w zakresie skutków wynikających z art. 362 k.c. z przyczynieniem się samych poszkodowanych, jednak pogląd ten nie spotkał się z aprobatą w doktrynie i został poddany krytyce. Z utrwalonej linii orzeczniczej ${ }^{35}$ wynika bowiem, że osoba zobowiązana, według przepisów o czynach niedozwolonych, do naprawienia szkody poniesionej przez małoletnie dziecko nie może na zasadzie art. 362 k.c. żądać zmniejszenia swego obowiązku odszkodowawczego wobec tego dziecka na tej podstawie, że szkoda pozostaje w związku przyczynowo-skutkowym także z zawinieniem rodziców poszkodowanego, wyrażającym się w braku należytego nadzoru. Inaczej z kolei należy oceniać przypisanie poszkodowanemu konsekwencji zachowania osób, za które według ustawy ponosi odpowiedzialność, jak zwierzchnik za podwładnego (art. 429 i 430 k.c.). Takie zachowania można klasyfikować jak działania samego poszkodowanego ${ }^{36}$.

W świetle przedstawionych problemów szczególnie istotne jest zapewnienie szerokiej ochrony ubezpieczeniowej, adekwatnej do potrzeb posiadaczy gospodarstw rolnych. Temu celowi służy tzw. test wymagań i potrzeb. Pozwala on wzmocnić ochronę klienta, który nie posiadając odpowiedniej wiedzy i doświadczenia, może dokonać niewłaściwego wyboru produktu ubezpieczeniowego lub usług finansowych ${ }^{37}$. W przypadku ubezpieczeń obowiązkowych badanie wymagań i potrzeb ubezpieczeniowych klienta jest bardziej złożone i wymaga uwzględnienia dodatkowych wymogów. Posiadacze gospodarstw rolnych powinni zadbać o sprecyzowanie w treści umowy ubezpieczenia składników gospodarstwa rolnego, objętych ochrona. Zwykle rolnikom oferowane są pakiety ubezpieczeń, których zakresem są objęte szkody wyrządzone osobom trzecim, będące następstwem śmierci, uszkodzenia ciała, rozstroju zdrowia, uszkodzenia lub zniszczenia mienia, jak również szkody powstałe w związku z ruchem pojazdów wolnobieżnych, będących w posiadaniu rolników i użytkowanych w związku z posiadaniem przez nich gospodarstwa rolnego. Ubezpieczenie może być rozszerzone na budynki rolnicze czy innego mienie będące w posiadaniu rolnika. Tak ogólny zakres ubezpieczenia wymaga jednak sprecyzowania w treści umowy albo w ogólnych warunkach ubezpieczenia.

2014 r., sygn. akt: I C 1073/11, niepubl.; G. Wolak, Odpowiedzialność za szkodę wyrzqdzonq przez psa wykorzystywanego przez rolnika użytkowo w gospodarstwie rolnym w świetle przepisów ustawy o ubezpieczeniach obowiqzkowych, „Prawo Asekuracyjne” 2017, nr 3, s. 46 i n.; wyrok SN z 12 kwietnia 2013 r., sygn. akt: IV CSK 565/12, LEX nr 1324321; I. Lipińska, Z problematyki ubezpieczeń rolnych i zwierzqt gospodarskich, „Przegląd Prawa Rolnego” 2012, nr 2, s. 51; uchwała SN z 20 czerwca 2017 r., sygn. akt: III CZP 114/16, OSNC 2017, nr 12, poz. 130; wyrok S0 w Sieradzu z 18 stycznia 2017 r., sygn. akt: I Ca 511/16, Legalis nr 1629986.

34. IV CR 484/82, OSPiKA 1984, Nr 1, poz. 4 z glosą kryt. A. Szpunara, tamże.

35. Wyroki SN z 16 marca 1963 r., sygn. akt: I CR 33/83, OSNCP 1983, nr 12, poz. 196; z dnia 22 września 1986 r., sygn. akt: IV CR 279/86, niepubl.; z dnia 5 listopada 2008 r., sygn. akt: I CSK 139/08, niepubl.; z dnia 16 marca 1983 r., I ICR 33/83, OSNCP 1983, nr 12, poz. 196.

36. Zob. szerzej: P. Sobolewski, [w:] Kodeks cywilny. Komentarz, [red.] K. Osajda, Legalis 2020.

37. Zob. Pytania i odpowiedzi do Zasad Ładu Korporacyjnego dla instytucji nadzorowanych ZŁK, https://www.knf. gov.pl/knf/pl/komponenty/img/ZLK_pytania___odpowiedzi_28-11-2014_39829.pdf [dostęp: 18.01.2020]. 
Dokonując syntetycznej analizy zagadnień, będących przedmiotem niniejszej glosy, należy stwierdzić, że linia orzecznicza kształtująca się na kanwie odpowiedzialności posiadacza gospodarstwa rolnego wymaga ujednolicenia. Jednocześnie samo poruszenie problematyki granic odpowiedzialności odszkodowawczej w gospodarstwach rolnych należy ocenić pozytywnie. Choć pojawiają się poglądy odmienne ${ }^{38}$, to wprowadzenie definicji gospodarstwa rolnego w kodeksie cywilnym ocenione zostało pozytywnie jako przemyślany zabieg legislacyjny, mający na celu zwiększenie ochrony własności rolniczej z jednoczesnym ograniczeniem ingerencji administracyjnej ${ }^{39}$. Choćby z tego względu definicję tę należy stosować uzupełniająco. Instrumentem pozwalającym na zabezpieczenie interesów ubezpieczającego jest szczegółowe wskazanie składników gospodarstwa rolnego przy dokonywaniu czynności prawnej ${ }^{40}$. Szczególną uwagę należy poświęcić przy tym inwentarzowi żywemu i zwierzętom gospodarskim, gdyż wyrządzenie przez nie szkody nadal może wzbudzać wiele wạtpliwości.

\section{Wykaz źródeł}

Agricultural Insurance Schemes. Summary report, November 2006, https://ec.europa.eu/agriculture/ sites/agriculture/files/external-studies/2006/insurance/summary_en.pdf [dostęp: 17.11.2019]. Borowczyk E., Zabezpieczenie społeczne, rodzina i jednostka, [w:] Europejskie Spotkanie Regionalne ISSA, Ubezpieczenia w rolnictwie, „Materiały i Studia” 1999, nr 3.

Budzinowski R., [w: Kodeks cywilny. Tom I. Komentarz. Art. 1-44911, Gutowski M. [red.], Warszawa 2016, Legalis/el.

Budzinowski R., [w:] Prawo rolne, Stelmachowski A. [red.], LexisNexis, Warszawa 2003.

Budzinowski R., Koncepcja gospodarstwa rolnego w prawie rolnym, Wydawnictwo Naukowe Uniwersytetu im. Adama Mickiewicza, Poznań 1992.

Budzinowski R., Pojęcie gospodarstwa rolnego według kodeksu cywilnego (rozważania na tle art. $55^{3}$ k.c. J, „Ruch Prawniczy, Ekonomiczny i Socjologiczny” 1991, nr 3.

Budzinowski R., Problemy ogólne prawa rolnego. Przemiany podstaw legislacyjnych i koncepcji doktrynalnych, Wydawnictwo Naukowe Uniwersytetu im. Adama Mickiewicza, Poznań 2008.

Budzinowski R., W kwestii statusu prawnego gospodarstwa rolnego jako przedsiębiorstwa, [w: ] Rozprawy z prawa prywatnego. Księga pamiqtkowa dedykowana Profesorowi Aleksandrowi Oleszce, Dańko-Roesler A., Jacyszyn J., Pazdan M., Popiołek W. [red.], Stowarzyszenie Notariuszy RP, Warszawa 2012.

Kiziewicz E., Odpowiedzialność rolnika za szkodę wyrzqdzona przez psa, „Monitor Ubezpieczeniowy” 2015, nr 63.

Kurowska T., Współczesne aspekty własności rolniczej, „Studia luridica Agraria” 2002, t. III. Lichorowicz A., Przedsiębiorstwo handlowe a przedsiębiorstwo rolne we włoski kodeksie cywilnym, [w:] Księga pamiqtkowa ku czci Profesora Janusz Szwaji. Prace Instytutu Prawa Własności Intelektualnej UJ, Barta J. [red.], Wydawnictwo Zakamycze, Kraków 2004.

38. Zob. T. Kurowska, Współczesne aspekty własności rolniczej, „Studia luridica Agraria” 2002, t. III, s. 43.

39. K. Stefańska, Pojęcia "nieruchomość rolna” $i$ "gospodarstwo rolne” w ujęciu kodeksu cywilnego $i$ ich znaczenie dla legislacji prawno rolnej, „Studia luridica Agraria” 2009, t. VII, s. 93.

40. Postanowienie SN z 9 grudnia 2009 r., sygn. akt: IV CSK 210/10, Legalis nr 414631. 
Lipińska I., Z problematyki ubezpieczeń rolnych i zwierzat gospodarskich, „Przegląd Prawa Rolnego” 2012, $\mathrm{nr} 2$.

Łobos-Kotowska D., Gospodarstwo rodzinne. Prawne formy organizacji, Wyższa Szkoła Zarządzania i Marketingu w Sosnowcu, Sosnowiec 2006.

Nawracała J., [w:] Prawo ubezpieczeń gospodarczych. Komentarz. Tom I. Komentarz do przepisów prawnych o funkcjonowaniu rynku ubezpieczeń, Brodecki Z., Glicz M., Serwach M. [red.], Wolters Kluwer, Warszawa 2010.

Pytania i odpowiedzi do Zasad Ładu Korporacyjnego dla instytucji nadzorowanych ZłK, https:// www.knf.gov.pl/knf/pl/komponenty/img/ZLK_pytania__odpowiedzi_28-11-2014_39829.pdf [dostęp: 18.01.2020].

Skowrońska-Bocian E., Warciński M., [w:] Kodeks cywilny. Tom I. Komentarz. Art. 1-44910, Pietrzykowski K. [red.], CH Beck, Warszawa 2015.

Stefańska K., Pojęcia „nieruchomość rolna” i „gospodarstwo rolne” w ujęciu kodeksu cywilnego i ich znaczenie dla legislacji prawno rolnej, „Studia luridica Agraria” 2009, t. VII.

Szymecka A., Gospodarstwo rolne w prawie włoskim - zagadnienia wybrane, „Przegląd Prawa Rolnego" 2009, nr 1[5].

Szymecka Gospodarstwo rolne w prawie włoskim - zagadnienia wybrane, „Przegląd Prawa Rolnego" 2009, nr 1.

Wolak G., Odpowiedzialność za szkodę wyrzqdzona przez psa wykorzystywanego przez rolnika użytkowo w gospodarstwie rolnym w świetle przepisów ustawy o ubezpieczeniach obowiqzkowych, „Prawo Asekuracyjne” 2017, nr 3.

Ziemba J., [w:] Ustawa o dystrybucji ubezpieczeń. Komentarz, Machulak P., Ziemba J. [red.], Legalis 2018.

\section{Gloss to the Judgment of the Supreme Court of 24 January 2017, Court file no. V CSK $163 / 16$}

The hereby commentary is an attempt of analysis of farmers insurance. The study contains reflections on the concepts of the agricultural holding. There are various definitions of the agricultural holding in the Polish legal system. They serve different purposes. The agricultural holding comprises assets of estate, which are related in functional terms and may vary in terms of quantity and type. There is a functional relationship among all components of the agricultural holding. It should also be noted that there are a lot different components of agricultural holding. Judicature took up an attempt of definite situations, in which tank and animals, for instance dogs or horses, are involved of insurance protection. In this article the Author analysis also Italian legal system. Furthermore, the article contains amendment, which are aimed at regulation insurance product to client's needs.

Keywords: agricultural holding, assets of estate, functional relationship, insurance, agricultural animals.

MGR ANETA PALECZNA - doktorantka w Instytucie Nauk Prawnych, Prawo Cywilne i Prawo Prywatne Międzynarodowe Uniwersytetu Śląskiego w Katowicach, aplikantka adwokacka przy ORA w Katowicach

nr ORCID: 0000-0001-7951-200 